\title{
PEMANFAATAN RUANG TERBUKA HIJAU DI RUMAH SUSUN Studi Kasus : Rumah Susun Kebon Kacang dan Bendungan Hilir I
}

\author{
Yosica Mariana \\ Architecture Department, Faculty of Engineering, Binus University \\ Jalan K.H. Syahdan No. 9, Palmerah, Jakarta Barat 11480 \\ ymariana@binus.edu
}

\begin{abstract}
One solution for meeting the needs of habitable housing for people, especially the middle to bottom is vertical housing or flats, this makes the availability of residential demand is increasing. In the process of vertical residential development should not only be limited to the provision of the physical aspects of the building, but also must consider the availability of green open space, which is based on the Law of Indonesia no. 26 of 2007 on Spatial Planning. Provision of green open space in the flats environment are very essential since beside becoming a place for socializing, open spaces are also has ecological function as a water catchment. Therefore, the purpose of this study was to determine the relationship between the user and the activities undertaken in the use of green open space in the flat. The methods of research used is descriptive method to provide an overview of the user involvement and activities undertaken in the use of green open space. The results showed that the use of green open spaces tend to be widely used by housewives and children paticularly in the morning and in the afternoon. The actvities include social interaction, play, sit and exercise.
\end{abstract}

Keywords: flats, green open space, activity

\begin{abstract}
ABSTRAK
Salah satu solusi bagi pemenuhan kebutuhan perumahan yang layak huni bagi masyarakat khususnya masyarakat menengah ke bawah adalah hunian vertikal atau rumah susun, hal ini membuat permintaan akan ketersediaan hunian ini semakin meningkat. Dalam proses pembangunan hunian vertikal sebaiknya tidak hanya terbatas pada penyediaan aspek fisik bangunannya saja tetapi juga harus memperhatikan ketersediaan fasilitas ruang terbuka hijau, dimana berdasarkan Undang-Undang RI no. 26 tahun 2007 mengenai Penataan Ruang. Penyediaan ruang terbuka pada rumah susun merupakan bagian dari lingkungan rumah susun yang sangat penting, karena ruang terbuka hijau selain menjadi wadah untuk bersosialisasi, dapat juga berfungsi secara ekologis yaitu sebagai daerah resapan air. Tujuan penelitian ini adalah mengetahui hubungan antara pengguna dan aktivitas yang dilakukan dalam pemanfaatan ruang terbuka hijau di lingkungan rumah susun. Metode penelitian menggunakan metode deskriptif untuk memberikan gambaran keterlibatan pengguna dan aktivitas yang dilakukan dalam memanfaatkan ruang terbuka hijau. Hasil penelitian menunjukkan bahwa pemanfaatan ruang terbuka hijau cenderung banyak digunakan oleh ibu rumah tangga dan anak - anak dalam kurun waktu pagi dan sore hari, dengan aktivitas yang dilakukan adalah berinteraksi sosial, bermain, duduk - duduk dan berolah raga.
\end{abstract}

Kata kunci: rumah susun, ruang terbuka hijau, aktivitas 


\section{PENDAHULUAN}

Berkembang pesatnya sebuah kota terutama kota metropolitan seperti Jakarta menjadikan kota Jakarta sebagai daya tarik bagi terjadinya proses urbanisasi. Hal ini menimbulkan permasalahan pada ketersediaan lahan bagi perumahan, sehingga Pemerintah Provinsi DKI Jakarta dituntut untuk dapat memanfaatkan lahan secara maksimal dan efisien. Salah satu solusi bagi pemenuhan kebutuhan perumahan yang layak huni bagi masyarakat khususnya masyarakat menengah ke bawah adalah hunian vertikal atau rumah susun sehingga permintaan akan ketersediaan hunian ini semakin meningkat. Sampai tahun 2012 sudah tersedia sebanyak 28.422 unit rumah susun di Provinsi DKI Jakarta (Data statistik Daerah Provinsi DKI Jakarta, 2013). Hal itu dapat dilihat pada tabel sebagai berikut :

Tabel 1 Rumah Susun Sederhana menurut Kota

\begin{tabular}{lccc}
\hline \multicolumn{1}{c}{ KOTA } & JUMLAH LOKASI & LUAS AREA (Ha) & JUMLAH UNIT \\
\hline Jakarta Selatan & 2 & 3,00 & 520 \\
Jakarta Timur & 15 & 73,24 & 9.401 \\
Jakarta Pusat & 10 & 23,73 & 7.297 \\
Jakarta Barat & 8 & 35,81 & 3.430 \\
Jakarta Utara & 13 & 95,92 & 7.774 \\
\hline DKI Jakarta & 48 & 231,70 & 24.442 \\
\hline \multicolumn{5}{c}{}
\end{tabular}

Dalam proses pembangunan hunian vertikal sebaiknya tidak hanya terbatas pada penyediaan aspek fisik bangunannya saja tetapi juga harus memperhatikan ketersediaan fasilitas ruang terbuk. Berdasarkan Undang-Undang RI no. 26 tahun 2007 mengenai Penataan Ruang bahwa luas RTH kota ditentukan adalah minimal $30 \%$ dari luas kota tersebut atau menurut Dirjen Penataan Ruang Departemen Pekerjaan Umum (2006) penentuan luas Ruang terbuka hijau (RTH) kota dapat diperhitungkan berdasarkan jumlah penduduk, di mana luas ruang terbuka hijau (taman) di lingkungan pemukiman untuk bermain dan berolah raga adalah $1,5 \mathrm{~m}^{2} / \mathrm{jiwa}$. Tetapi dengan adanya pertambahan jumlah penduduk yang terus menerus menyebabkan semakin sempit lahan yang digunakan untuk pemukiman, sehingga terkadang penyediaan ruang terbuka dalam suatu lingkungan terabaikan. Padahal ruang terbuka tersebut dapat menjadi wadah bagi masyarakat lingkungan tersebut untuk melakukan interaksi sosial. Selain itu juga ruang terbuka hijau memiliki fungsi secara ekologis, arsitektur dan ekonomi, antara lain (Supriyatno, 2009): (1) Secara ekologis, ruang terbuka yang hijau dapat menurunkan temperatur kota, mengurangi polusi udara, mencegah banjir dan meningkatkan kualitas air tanah. (2) Secara sosial budaya, keberadaan ruang terbuka dapat memberikan fungsi sebagai ruang berinteraksi, sarana rekreasi dan sebagai tanda kota berbudaya. Wujudnya seperti taman kota, lapangan olah raga atau makam. (3) Secara arsitektur, ruang terbuka dapat meningkatkan keindahan dan kenyamanan kota melalui keberadaan taman-taman kota, jalur-jalur hijau dan jalanjalan kota. (4) Sementara ditinjau dari sisi ekonomi, jika ruang terbuka hijau ini dikelola dengan baik dan menarik maka akan mengundang penghuni kota hadir berekreasi dan membangkitkan sektor ekonomi di sekitarnya seperti jasa parkir, warung, tempat makan dan sebagainya.

Menurut Piddington dalam Anwar (1998), dikatakan bahwa salah satu kebutuhan manusia yang bersifat universal adalah kebutuhan sosial yaitu salah satunya adalah berkomunikasi/berinteraksi serta melakukan kegiatan bersama dengan orang lain. Dengan demikian, keberadaan ruang terbuka hijau atau taman yang merupakan bagian dari lingkungan rumah susun dapat memberikan konstribusi positif terhadap ruang sosial bagi para penghuni dimana ibu rumah tangga merupakan kelompok yang paling sering berada di lingkungan rumah susun sepanjang hari (Yosica, 2011). Mereka bahkan menggunakan ruang terbuka yang ada di rumah susun untuk berinteraksi dengan penghuni lain. 
Berdasarkan Permendagri No. 1 tahun 2007, ruang terbuka dinyatakan sebagai ruang-ruang dalam kota atau wilayah yang lebih luas, baik dalam bentuk area/kawasan maupun dalam bentuk area memanjang/jalur, di mana lebih bersifat terbuka dalam penggunaan dan pada dasarnya tanpa bangunan. Lebih spesifik lagi, ruang terbuka hijau (RTH) adalah bagian dari ruang terbuka yang pemanfaatannya sebagai tempat tumbuh tanaman, baik yang tumbuh secara alamiah maupun yang sengaja ditanam (budi daya tanaman), seperti lahan pertanian, pertamanan, perkebunan dan sebagainya (UU RI No. 26 Tahun 2007).

Sedangkan tujuan pengadaan dan penataan RTH di wilayah perkotaan menurut Permendagri No. 1 Tahun 2007, yaitu: (1) Menjaga keserasian dan keseimbangan ekosistem lingkungan. (2) Mewujudkan keseimbangan antara lingkungan alam dan lingkungan buatan bagi kepentingan masyarakat. (3) Meningkatkan kualitas lingkungan yang sehat, indah, bersih, dan nyaman.

Proporsi RTH pada wilayah kota paling sedikit $30 \%$ dari luas wilayah kota, ini merupakan ukuran minimal untuk menjamin keseimbangan ekosistem kota, yang selanjutnya akan meningkatkan ketersediaan udara bersih yang diperlukan masyarakat, serta dapat meningkatkan nilai estetika kota. (UU RI No. 26 Tahun 2007). Oleh karena itu, pengadaan ruang terbuka hijau (taman) pada lingkungan permukiman adalah sangat penting. Pertumbuhan pembangunan rumah susun yang marak di Jakarta seharusnya juga memperhatikan ketersediaan ruang terbuka hijau, karena selain sebagai paru-paru kawasan juga dapat menjadi daerah resapan air.

Untuk meningkatkan kualitas lingkungan permukiman tersebut, salah satu cara yang dapat ditempuh adalah menyediakan ruang terbuka bersama bagi masyarakat, yang dapat menciptakan interaksi satu sama lain, juga tersedianya sarana dan prasarana bermain bagi anak-anak serta dapat menampung berbagai aktivitas sosial kemasyarakatan lainnya. Salah satu upaya secara fisik dalam pengendalian dan peningkatan mutu lingkungan permukiman adalah dengan adanya pengadaan RTH/taman pada lingkungan permukiman. Berdasarkan hal tersebut, penelitian ini dilakukan untuk mengindentifikasi pemanfaatan dan kebutuhan ruang terbuka hijau dalam lingkungan rumah susun, yaitu pada rumah Susun Kebon Kacang dan Bendungan Hilir I. Dengan mengetahui pemanfaatan serta kebutuhan akan ruang terbuka hijau ini, diharapkan dapat memberikan masukan secara lebih spesifik bagi pengembang dan pemerintah daerah setempat dalam upaya penyediaan ruang terbuka hijau sebagai salah satu fasilitas di lingkungan rumah susun yang diharapkan dapat digunakan oleh para penghuni sebagai suatu wadah sosial selain dapat memberikan keseimbangan dalam ekosistem.

\section{METODE}

Dalam hal ini, penelitian menggunakan metode deskriptif analisis yang bertujuan untuk mengetahui, mengidentifikasi dan menemukan pola pemanfaatan dan kebutuhan ruang terbuka hijau di dalam lingkungan rumah susun. Pemilihan subjek dan lokasi penelitian dilakukan dengan menggunakan studi kasus pada dua rumah susun yang memiliki kategori yaitu berada di daerah perkotaan dan cukup lama dihuni (lebih dari lima tahun dan bersifat permanen), yaitu Rumah Susun Kebon Kacang dan Bendungan Hilir I. Pengumpulan data dilakukan melalui pengamatan langsung, wawancara dan studi pustaka. Metode pengamatan dilakukan untuk mendapatkan gambaran mengenai gambaran pemanfaatan dan kebutuhan ruang terbuka, melalui interprestasi dan penginderaan jauh. Pelaksanaan ini dilakukan dalam tiga tahapan yaitu tahap persiapan (studi pustaka dan pengumpulan data dengan penginderaan jauh), tahap interprestasi, dan tahap penyajian hasil. Sedangkan metode wawancara dilakukan untuk mendapatkan data-data mengenai pola kebutuhan akan ruang terbuka hijau, di mana populasi yang diambil sebagai subjek penelitian adalah penghuni rumah susun tersebut, teknik sampling yang digunakan adalah stratified random sampling, teknik ini banyak digunakan untuk mempelajari karakteristik yang berbeda dan juga untuk mengurangi pengaruh faktor heterogen. Dalam teknik ini dilakukan pembagian elemen-elemen populasi ke dalam strata, untuk selanjutnya dari masing-masing strata dipilih sampel secara random (acak) sesuai proporsinya. 


\section{HASIL DAN PEMBAHASAN}

Pengamatan dilakukan pada dua rumah susun yaitu rumah susun Kebon Kacang dan Bendungan Hilir I, kedua rumah susun ini sudah bersifat permanen dan cukup lama dihuni. Dari hasil pengamatan tersebut maka diperoleh kondisi umum sebagai berikut:

Tabel 2 Kondisi Umum Rumah Susun

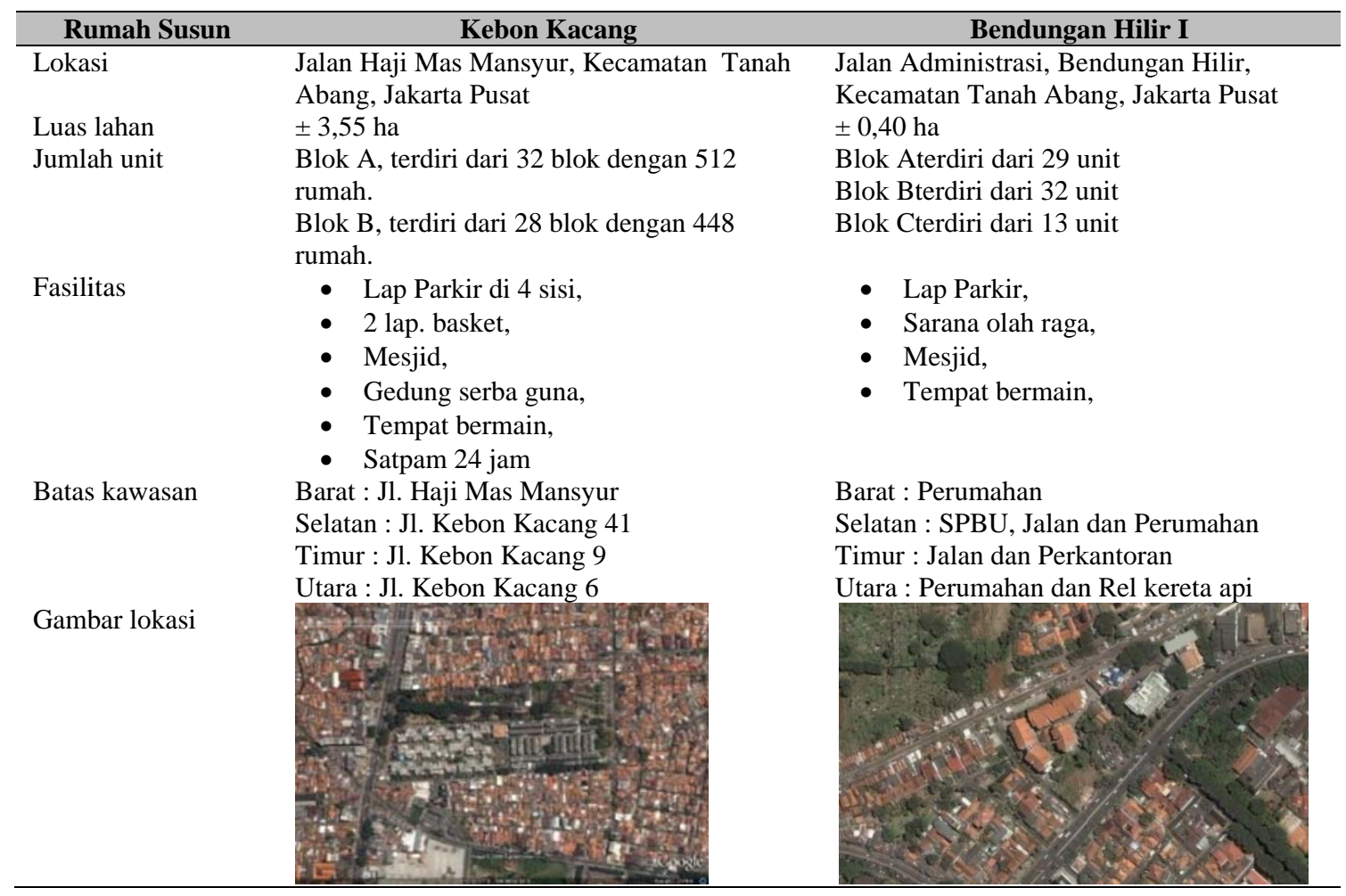

Sumber: Dokumentasi Penelitian Arsitektur Binus

Dari hasil pengamatan di lapangan yang dilakukan pada rumah susun Tanah Abang, satusatunya ruang terbuka yang cukup menonjol adalah ruang terbuka yang berada di dalam kompleks rumah susun, sebagian ada yang dipergunakan sebagai lapangan olah raga, koridor-koridor jalan dan ruang terbuka hijau.
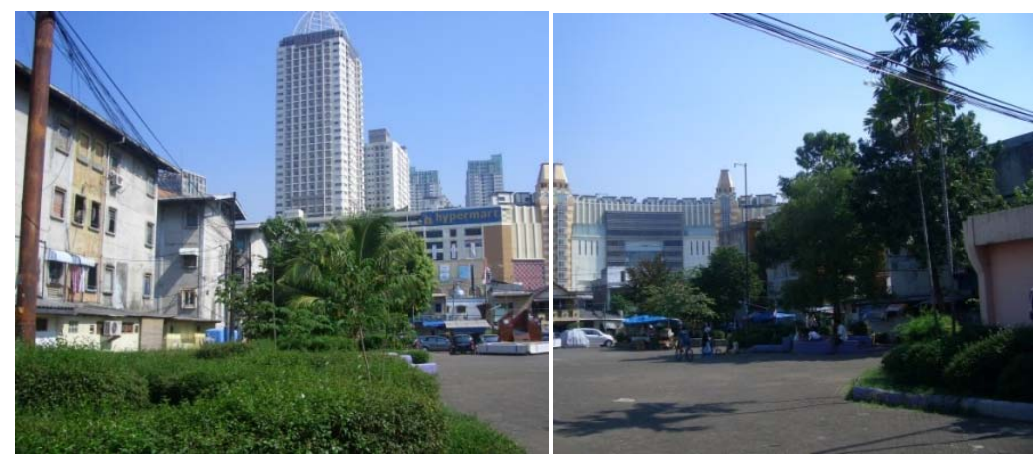

Gambar 1 Ruang terbuka di dalam kompleks rumah susun Sumber : Dokumentasi Penelitian Arsitektur Binus 


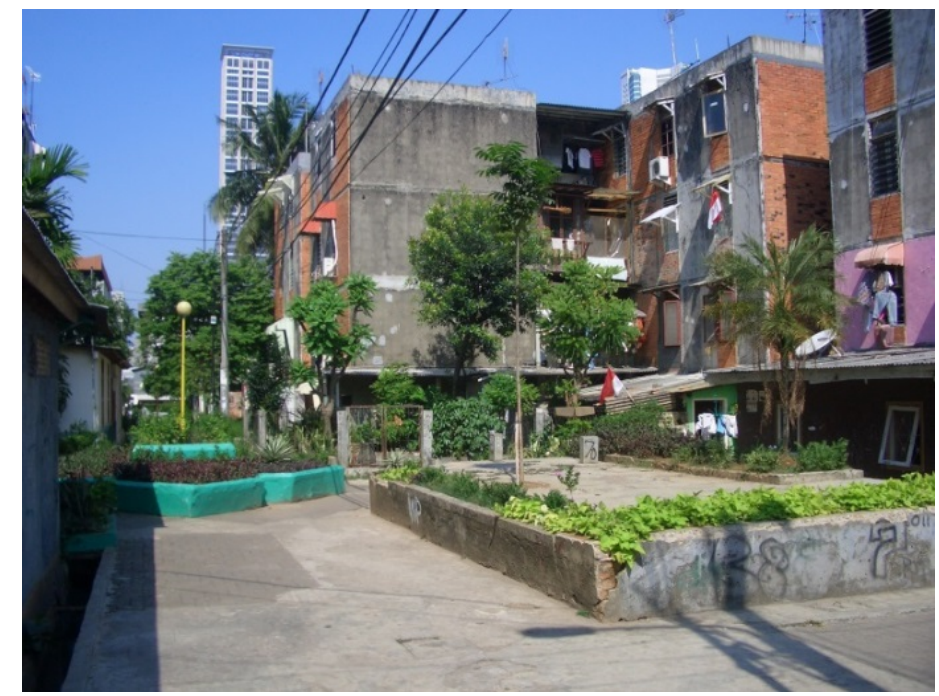

Gambar 2 Ruang terbuka hijau sebagai taman sebagai unsur penghijauan dalam kompleks rusun Sumber : Dokumentasi Penelitian Arsitektur Binus

Sedangkan untuk ruang terbuka hijau (RTH) yang ada betul-betul dimanfaatkan sebagai taman, begitu pula lapangan olah raga yang sering digunakan penghuni rusun di sore hari atau akhir minggu. Tetapi sekarang ini ruang terbuka yang ada sudah banyak mengalami perubahan pemanfaatan terutama ruang terbuka yang berupa koridor jalan yang banyak digunakan untuk parkir kendaraan penghuni rusun.

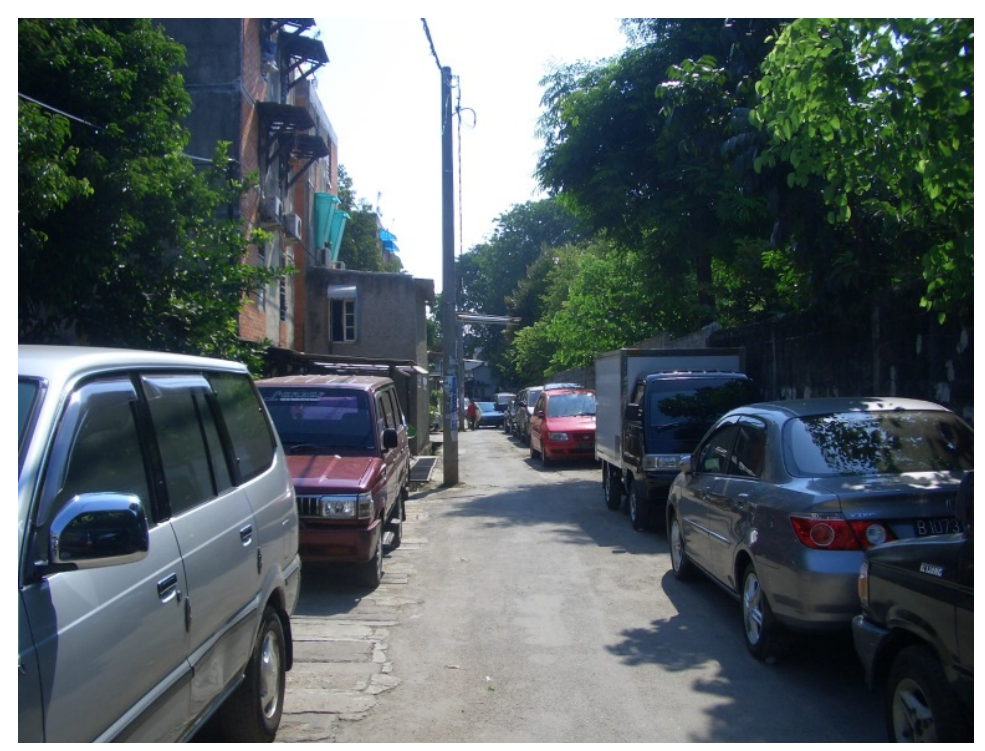

Gambar 3 Pemanfaatan koridor jalan oleh penghuni rumah susun Sumber : Dokumentasi Penelitian Arsitektur Binus

Sedangkan pangamatan yang dilakukan pada Rusun Bendungan Hilir I diperoleh hasil bahwa rumah susun ini juga memiliki ruang terbuka yang cukup luas di lahannya sendiri, hampir sama luasnya dengan luas lantai blok bangunan rusunnya. Saat ini, ruang terbuka yang ada tersebut dimanfaatkan untuk parkir kendaraan. 


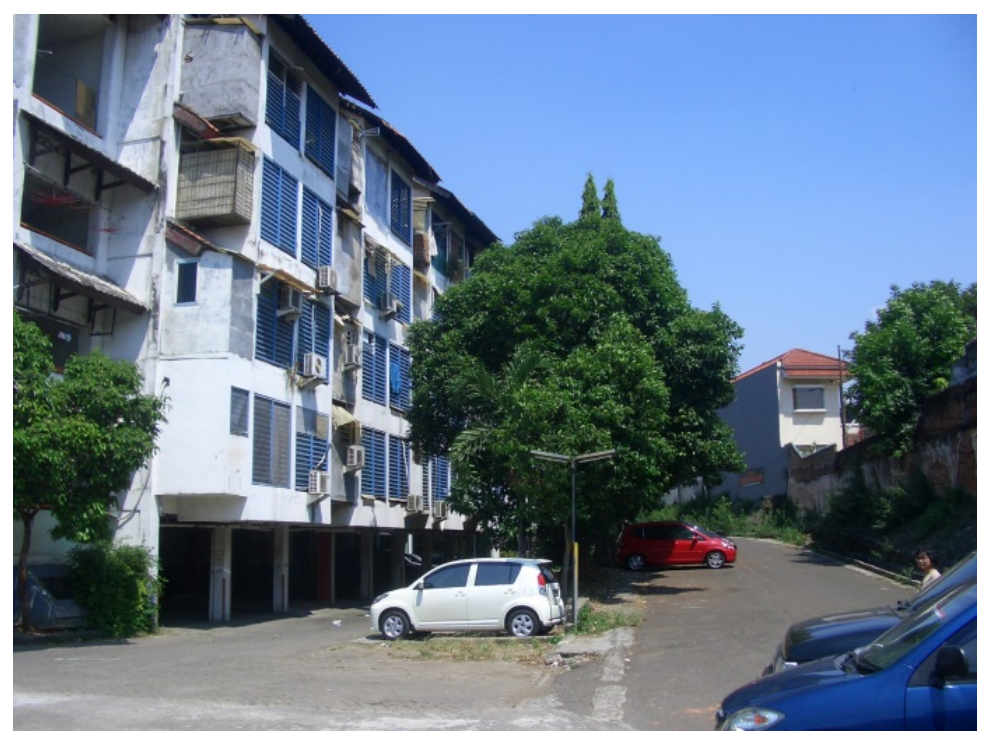

Gambar 4 Pemanfaatan ruang terbuka oleh penghuni rumah susun Sumber : Dokumentasi Penelitian Arsitektur Binus

Dan untuk ruang terbuka hijau yang cukup luas yaitu sekitar $\pm 300 \mathrm{~m} 2$ berada ditengah-tengah kompleks bangunan rusun. Awalnya, ruang terbuka ini hanya digunakan sebagai taman, namun kemudian dibangun mesjid pada setengah bagiannya beserta teras dan ruang wudhu sehingga saat ini yang masih berupa taman hanya tinggal setengah bagian. Meskipun ada beberapa tanaman besar di taman tersebut namun secara keseluruhan kondisi taman ini kurang terawat, penuh sampah dedaunan dan asesoris taman (bangku dan gazebo) yang letaknya tidak beraturan dan terlihat kotor. Hal ini juga menandakan bahwa penghuni rusun jarang menggunakan taman tersebut. Taman tersebut hanya berfungsi sekedar akses keluar masuk antara tempat parkir dan tangga vertikal yang menghubungkan ke unit rusun masing-masing penghuni.

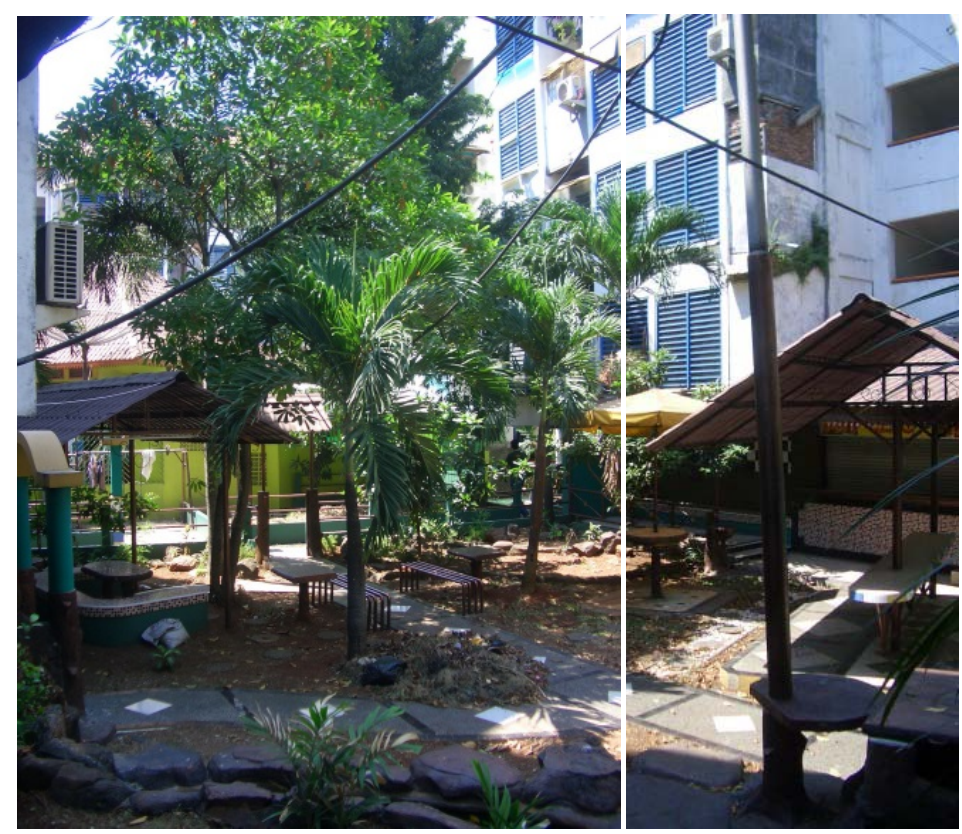

Gambar 5 Pemanfaatan ruang terbuka hijau oleh penghuni rumah susun Sumber : Dokumentasi Penelitian Arsitektur Binus 
Dan berdasarkan hasil wawancara pada dua lokasi rumah susun, kondisi dan pemanfaatan ruang terbuka hijau (RTH) adalah sebagai berikut:

Tabel 3 Fungsi, Pengguna dan Aktivitas yang dilakukan di Rumah Susun

\begin{tabular}{|c|c|c|c|c|c|}
\hline $\begin{array}{c}\text { Nama Rumah } \\
\text { Susun }\end{array}$ & $\begin{array}{c}\text { Fungsi Ruang } \\
\text { Terbuka Hijau } \\
\end{array}$ & Pengguna & Aktivitas umum & Kondisi & Luas \\
\hline $\begin{array}{l}\text { Rumah Susun } \\
\text { Tanah Abang }\end{array}$ & $\begin{array}{l}\text { Taman serbaguna } \\
\text { dan lahan } \\
\text { terbengkalai }\end{array}$ & $\begin{array}{l}\text { - Ibu Rumah Tangga } \\
\text { - Remaja } \\
\text { - Anak-anak }\end{array}$ & $\begin{array}{l}\text { Interaksi sosial, } \\
\text { bermain, olah } \\
\text { raga, acara khusus }\end{array}$ & $\begin{array}{l}\text { - Cukup terawat } \\
\text { - Panas (siang hari) } \\
\text { - Sifat menyebar }\end{array}$ & 1,0 ha \\
\hline $\begin{array}{l}\text { Rumah Susun } \\
\text { Bendungan Hilir } 1\end{array}$ & Taman serbaguna & $\begin{array}{l}\text { - Ibu Rumah Tangga } \\
\text { - Remaja } \\
\text { - Anak-anak }\end{array}$ & $\begin{array}{l}\text { Interaksi sosial, } \\
\text { bermain }\end{array}$ & $\begin{array}{l}\text { - Tidak terawat } \\
\text { - Teduh }\end{array}$ & $300 \mathrm{~m} 2$ \\
\hline
\end{tabular}

Sumber : Dokumentasi Penelitian Arsitektur Binus

Jika mengacu pada Undang-undang RI No. 26 Tahun 2007 yang mengatakan bahwa luas ruang terbuka hijau 30\% dari luas lahan, maka dapat disimpulkan sebagai berikut :

Tabel 4 Luas RTH Rumah Susun berdasarkan Presentase luas RTH

\begin{tabular}{lcccc}
\hline Nama Rumah Susun & Luas Lahan & Luas Ruang Terbuka & Presentase RTH & Status \\
\hline $\begin{array}{l}\text { Rumah Susun Tanah } \\
\text { Abang }\end{array}$ & $35.500 \mathrm{~m} 2$ & $10.000 \mathrm{~m} 2$ & $28,17 \%$ & Kurang \\
$\begin{array}{l}\text { Rumah Susun } \\
\text { Bendungan Hilir I }\end{array}$ & $4.000 \mathrm{~m} 2$ & $300 \mathrm{~m} 2$ & $5,63 \%$ & Sangat kurang \\
\hline
\end{tabular}

Sumber : Dokumentasi Penelitian Arsitektur Binus

Dari data-data di atas maka dapat disimpulkan bahwa jika mengacu pada Undang-undang RI No. 26 Tahun 2007 yang mengatakan bahwa luas ruang terbuka hijau adalah 30\% dari luas lahan, maka pada dua lokasi penelitian ini ternyata keberadaan ruang terbuka hijau di kedua rumah susun tersebut tidak mencukupi karena luas RTH yang ada berada di bawah 30\% dari luas lahan.Sedangkan untuk bentuk ruang terbuka hijau yang ada antara dua lokasi rumah susun tersebut tidak terlalu banyak berbeda, hanya dari kondisinya saja ada yang terawat dan ada yang kurang terawat, hal ini dimungkinkan karena kurangnya pemeliharaan dari pengelola dan penghuni lingkungan rumah susun. Dan jika berdasarkan Dirjen Penataan Ruang Departemen Pekerjaan Umum (2006) dikatakan bahwa penentuan luas Ruang terbuka hijau (RTH) kota juga dapat diperhitungkan berdasarkan jumlah penduduk, dimana luas ruang terbuka hijau (taman) di lingkungan pemukiman untuk bermain dan berolah raga adalah 1,5 m2/jiwa, maka diperoleh hasil sebagai berikut:

Tabel 5 Luas RTH Rumah Susun berdasarkan Jumlah Penduduk

\begin{tabular}{|c|c|c|c|c|}
\hline Nama Rumah Susun & Jumlah Penghuni & $\begin{array}{c}\text { Luas Ruang } \\
\text { Terbuka/rusun }\end{array}$ & Luas RTH/jiwa & Kondisi \\
\hline $\begin{array}{l}\text { Rumah Susun Tanah } \\
\text { Abang }\end{array}$ & 3840 jiwa & $10.000 \mathrm{~m} 2$ & 2,6 & Mencukupi \\
\hline $\begin{array}{l}\text { Rumah Susun } \\
\text { Bendungan Hilir I }\end{array}$ & 296 jiwa & $300 \mathrm{~m} 2$ & 1,01 & Tidak mencukupi \\
\hline
\end{tabular}

Dari tabel di atas, maka dapat disimpulkan bahwa Rumah Susun Kebon Kacang masih mempunyai ruang terbuka hijau yang cukup sesuai dengan perhitungan RTH berdasarkan jumlah penduduk yang ada pada setiap blok, sedangkan pada rumah susun Bendungan Hilir I tidak 
mencukupi. Selain itu juga wawancara dilakukan untuk memperoleh data mengenai pengguna ruang terbuka hijau, aktivitas yang dilakukan dan waktu yang biasanya digunakan pada area ruang terbuka hijau. Dan diperoleh hasil sebagai berikut :

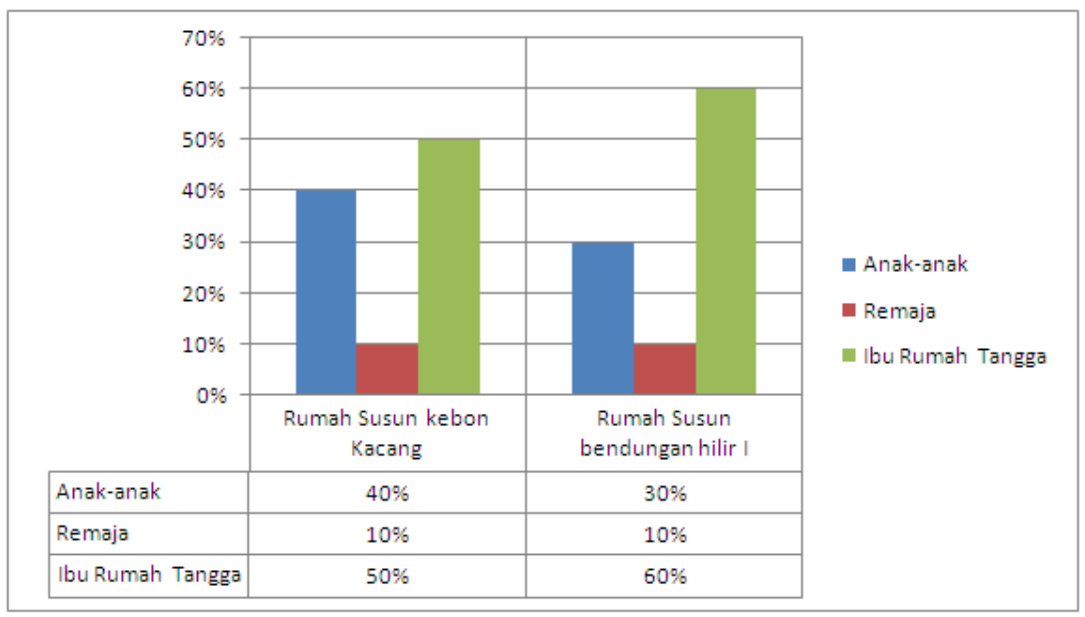

Gambar 6 Pengguna Ruang Terbuka Hijau (N=40/rumah susun) Sumber : Dokumentasi Penelitian Arsitektur Binus

Pengguna rumah susun umumnya terdiri dari 3 golongan yaitu anak-anak, remaja dan ibu rumah tangga, dimana pengguna terbesar pada kedua rumah susun tersebut adalah Ibu Rumah Tangga, pengguna kedua terbesar adalah anak-anak dan pengguna ketiga adalah remaja.

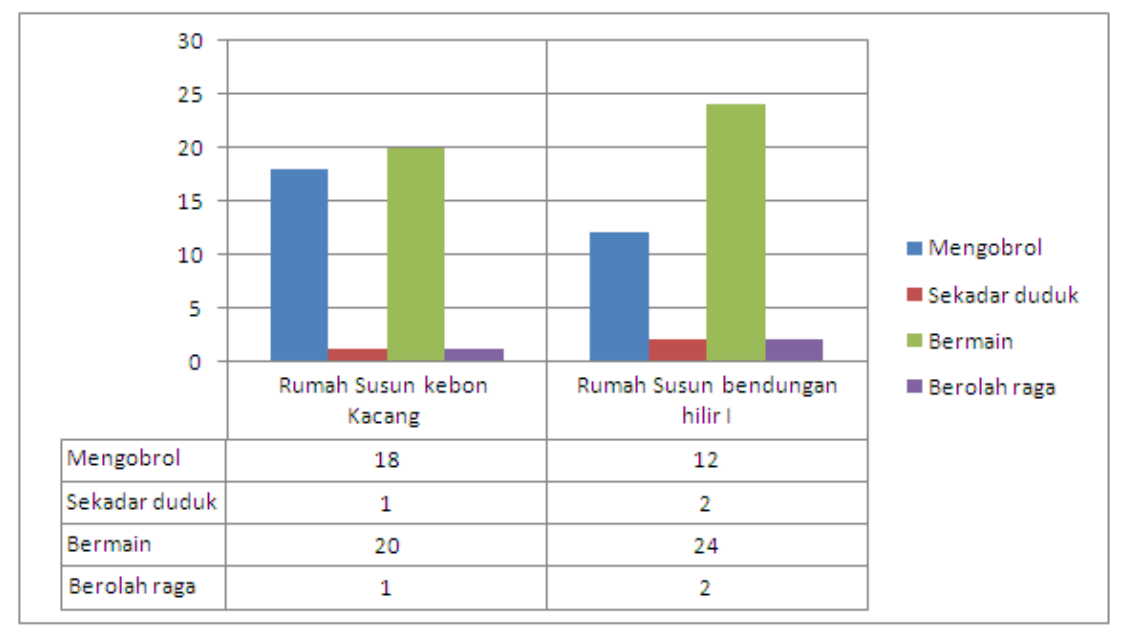

Gambar 7 Aktivitas penghuni rumah susun (N=40/rumah susun) Sumber : Dokumentasi Penelitian Arsitektur Binus

Untuk aktivitas yang dilakukan pada ruang terbuka hijau (taman) tersebut adalah bermain, mengobrol, berolah raga ataupun hanya sekedar duduk saja. Untuk waktu berkumpul, biasanya dilakukan pada pagi dan sore hari. 


\section{SIMPULAN}

Keberadaan ruang terbuka hijau pada rumah susun cenderung berubah karena adanya penambahan kebutuhan akan ruang, sehingga secara umum kurang dari standar yang telah ditentukan yaitu 30\% dari luas lahan, walaupun berdasarkan jumlah penduduk masih ada yang masih mencukupi. Selain itu, pemanfaatan ruang terbuka hijau umumnya banyak digunakan oleh ibu rumah tangga, anakanak dan remaja dengan aktivitas yang biasa dilakukan adalah bersosialisasi, bermain, sekedar dudukduduk atau olahraga. Aktivitas ini cenderung dilakukan pada pagi dan sore hari saja.

\section{DAFTAR PUSTAKA}

Anwar. (1998). Analisis Model Seting Ruang Komunal Sebagai Sarana Kegiatan Interaksi Sosial Penghuni Rumah Susun. Studi kasus: Rumah Susun Pekunden dan Sombo. Tesis tidak diterbitkan. Semarang: UNDIP.

Mariana, Y. (2011). Pola Aktivitas Ibu Rumah Tangga Terhadap Pemanfaatan Ruang Terbuka di Rumah Susun. Jurnal ComTech, 02(02). ISSN 2087-124.

Permendagri No. 1 tahun 2007 mengenai Ruang Terbuka

Supriyatno, Budi. (2009). Manajemen Tata ruang. Jakarta: Media Brilian.

Undang-Undang Republik Indonesia Nomor 16 Tahun 1985 tentang Rumah Susun.

Undang-Undang Republik Indonesia Nomor 26 tahun 2007 mengenai Penataan Ruang Jakarta dalam Angka 2013 